\title{
EKONOMIJA SMISLA I VREMENSKA DETERMINIRANOST POJEDINCA
}

\author{
Marko Šundov
}

\author{
Stano-uprava d.o.o. \\ Ulica Mike Tripala 6, 21000 Split \\ e-mail: markosundov2@gmail.com
}

\begin{abstract}
Sažetak
Vrijeme u kontekstu prevladavajuće globalne ekonomske paradigme determinira ponaśanje pojedinca u svim područjima društvenog djelovanja. Kult vremena i značaj upravljanja vremenom postaje ključna odrednica u djelovanju pojedinca spram ciljeva svoje potpune samorealizacije. Struktura i obujam vremena kojim raspolaže suvremeni pojedinac uvelike je determinirana ekonomskim procesima koji su nametnuti svim ostalim društvenim područjima unutar kojih isti djeluje. Gubitak mogućnosti upravljanja strukturom i obujmom svog vremena pojedinca stavlja u podredeni položaj spram procesa koji ga okružuju te ga čini podložnim utjecajima raznih interesnih skupina. Materijalizam pokretan profitom razvija nagonsku potrebu pojedinca za imanjem, a što za posljedicu ima dualnost vremena tj. vrijeme je definirano odrednicom rada i potrošnje. Nasilno djelovanje pojedinca spram prirodnog vremena za rezultat ima generiranje sve većih i pogubnijih socio-ekoloških kriza koje nagrizaju temelje civilizacijskih tekovina suvremenih druśtava. Izjednačavanjem vremena s novcem te istovremenim poticanjem nagonske potrebe za imanjem pojedinac je izložen kontinuiranom komprimiranju vremena i ubrzanju svojih svakodnevnih aktivnosti. Život postaje sve intenzivniji i kompleksniji te pojedinac postaje žrtva vlastitih težnji, što stvara dojam „nemogućnosti u svijetu svemogućnosti". Stoga se nameće potreba redefiniranja postojećih ekonomskih modela te vraćanje vremena u okvire unutar kojih će pojedinac biti u stanju povećati svoju mogućnost upravljanja istim, tj. što je moguće više uskladiti svoje vrijeme sprirodnim vremenom. Ekonomija smisla upravo svojim djelovanjem na vrijeme želi upravljati cjelovito svim društvenim procesima koji su važni za dugoročni uravnoteženi razvoj te ekonomiju podrediti pojedincu (za razliku od postojećeg modela unutar kojeg je pojedinac podređen ekonomskim procesima i ne može na njih utjecati).
\end{abstract}

Ključne riječi: upravljanje vremenom, dualnost vremena, prirodno vrijeme, socio-ekološka kriza, ekonomija smisla

\section{UVOD}

Prostor i vrijeme oduvijek su bili dvije ključne dimenzije čovjekove egzistencije, ali se tijekom čovjekove kulturne evolucije različito percipiraju (Cifrić i Trako, 2010). Prostor u kojem se kreće suvremeni pojedinac determiniran je vremenskim varijablama koje se razlikuju po svom intenzitetu, obujmu i strukturi. Razumijevanje vremena zahtjeva spoznavanje veze između njegovih različitih aspekata kao i svih ukupnosti u njihovom 
dinamičkom odnosu. Na taj način ne samo da se omogućava, već se i nameće pristup koji nadilazi postojeće perspektive. Ovo iziskuje nove načine razumijevanja i drugačiju upotrebu postojećih koncepata (Adam, 1990). Tehnološki razvoj omogućio je pojedincu bržu prostornu pokretljivost (dostupnost pojedinih točaka unutar prostora postala je jednostavnija i vremenski kraća) no istovremeno je utjecao na prioritete njegovih vremenskih varijabli. Ove izmjene svojim utjecajem značajno determiniraju globalne procese kao i same procese unutar društvenih sustava. Veća se prostorna dostupnost zbog akceleracije vremenskih varijabli anulirala te je pojedinac suprotno očekivanom komprimirao svoj prostor koji je ekološki preopteretio. Ovaj trend iskazuje se kroz sve veću urbanizaciju našeg planeta te stvaranja neuralgičnih čvorišta gdje se odvijaju društveni procesi unutar manjeg prostora napučenog velikim brojem dionika (Goodstein, 1999). Neuravnoteženost vremenskih varijabli uzrokovana je isključivošću prioriteta ekonomskog vremena $\left(\mathrm{T}_{\mathrm{en}}\right)$ nad društvenim $\left(\mathrm{T}_{\mathrm{dr}}\right)$ i ekološkim $\left(\mathrm{T}_{\mathrm{ek}}\right)$ vremenom koji definiraju prostor djelovanja suvremenog pojedinca (Slika 1). Ekonomsko vrijeme kao pojam predstavlja vrijeme koje pojedinac troši kako bi realizirao svoju potrebu za imanjem (egzistencijalnih ili neegzistencijalnih dobara / usluga). Ono se dijeli na vrijeme rada kao procesa stjecanja financijskih sredstava te obujam potrošnje koji je determinirano nizom čimbenika, a direktno je uvjetovana obujmom financijskih sredstava akumuliranih radom (fizičkim ili umnim). Društveno vrijeme kao pojam determinirano je vremenom djelovanja pojedinca izvan aktivnosti koje su direktno ili indirektno vezane za stjecanje egzistencijalnih ili neegzistencijalnih dobara, a čime se podiže njegova razina uključivosti u društvene procese (političke, sportske, kulturne, humanitarne i sl.). Ekološko vrijeme kao pojam predstavlja ono vrijeme koje je pojedinac spreman izdvojiti kako bi umanjio štetu koju ekonomskim i društvenim djelovanjem nanosi prirodnom okruženju (bilo na lokalnoj ili globalnoj razini).

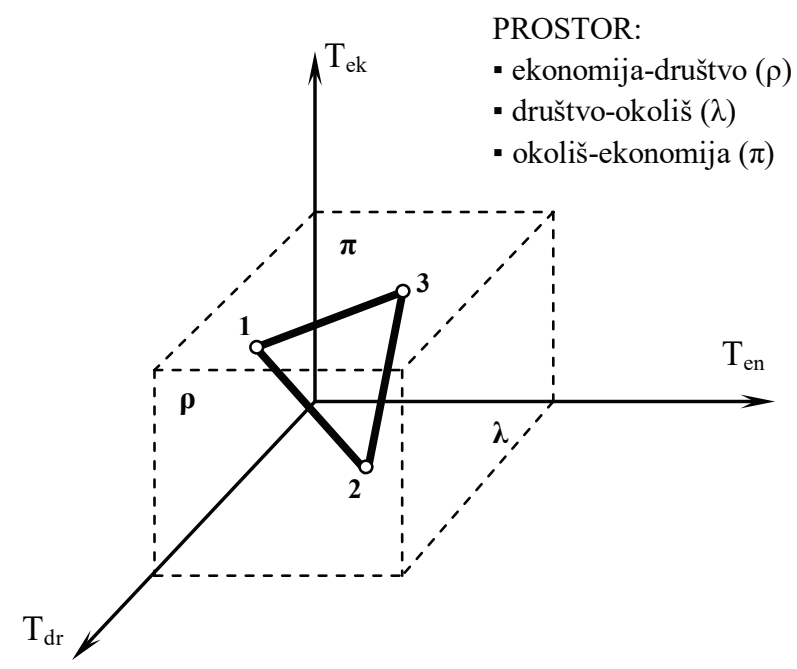

Slika 1. Prostor vremenske determiniranosti pojedinca 
Vremenski prostor suvremenog pojedinca omeđen je trima ravninama $\pi$, $\rho$ i $\lambda$ koje determiniraju prioritete njegovog djelovanja. Prevladavajuće ekonomsko vrijeme $\left(\mathrm{T}_{\mathrm{en}}\right)$ generira intenzitet utjecaja na društveno $\left(\mathrm{T}_{\mathrm{dr}}\right)$ i ekološko $\left(\mathrm{T}_{\mathrm{ek}}\right)$ vrijeme. Međuodnos ekonomskog i društvenog vremena prikazan je točkom 1 koja se nalazi u ravnini $\rho$. Dominantnim odnosom spram društvenog vremena ekonomsko vrijeme direktno utječe na međuodnos društvenog vremena i ekološkog vremena determiniran je točkom $2 \mathrm{u}$ ravnini $\lambda$. Smanjeni intenzitet djelovanja društvenog vremena spram ekološkog vremena u korelaciji je s međuodnosom ekološkog i ekonomskog vremena, a što je iskazano točkom 3 u ravnini $\pi$. Položaj točaka 1,2 i 3 u pojedinoj ravnini nije statičan već je kontinuirano izložen dinamičkim promjenama (pulsiranjima) i determiniran trima prostornim vremenskim dimenzijama: prošlost, sadašnjost i budućnost. Kontinuiranost i struktura promjena utječe na oblik prostornog trokuta s točkama 1, 2 i 3 kao njegovim vrhovima, iz kojeg se mogu iščitavati intenziteti međuutjecaja vremena unutar pojedinih ravnina (Slika 1). Jednakokračnost prostornog trokuta simulira ravnotežu ekonomskog, ekološkog i društvenog vremena u određenom prostoru djelovanja pojedinca tj. veća deformacija / nejednakost prostornog trokuta može ukazati na određene vrste anomalija (ekoloških, društvenih ili ekonomskih). Zahvaljujući svojoj novostečenoj fleksibilnosti i ekspanzivnosti, moderno vrijeme postalo je ponajprije oružje u osvajanju prostora. U modernoj borbi između vremena i prostora, prostor je bio kruta i flegmatična, glomazna i troma strana, kadra voditi samo obrambeni, rovovski rat - i kao takav prepreka elastičnom napredovanju vremena. Vrijeme je bilo aktivna i dinamična strana u toj borbi, ona koja je uvijek bila u ofenzivi: napadačka, osvajačka i kolonizatorska sila. Brzina kretanja i dostupnost sredstava za bržu pokretljivost postojano su se u moderna vremena uzdigle do položaja glavnog instrumenta moći i dominacije (Bauman, 2011). Kretanje pojedinca u vremenskom prostoru sve je više posljedica eksternih procesa na koje on sam ima sve manji utjecaj, a što je značajnim dijelom zasluga sveprisutne doktrine individualizacije i partikularnosti u procesu samorealizacije. Upravo kontrola samoupravljivosti obujmom i strukturom vremena pojedinca, predstavlja ključan proces za dugoročno održivi i uravnoteženi razvoj našeg planeta (Stiglitz, 2009). Stoga postojeću platformu ekonomske filozofije temeljene na profitu i neograničenom rastu treba zamijeniti nova ekonomska filozofija utemeljena na alatima koji će kreirati ekonomiju primjerenu čovjeku tzv. ekonomiju smisla. Prema standardima danas prevladavajuće neoliberalne doktrine smisleno je ono djelovanje koje pojedincu povećava „komoditet“ tj. ono djelovanje kojim pojedinac podiže razinu svog materijalnog blagostanja bez obzira na posljedice koje se pri tom generiraju. Ovakav pristup smislenom djelovanju imao je opravdanje s gledišta rasta gospodarstva i razvijanja novih tehnoloških rješenja kojima se podiže razina standarda življenja. No s gledišta nesmiljene devastacije „biokapaciteta“ i prirodnih resursa rezultiralo je dostizanjem kritične točke pri kojoj priroda svojim djelovanjem nastoji zadržati ravnotežu koja joj je narušena čovjekovim aktivnostima u težnji za svojim komoditetom. Stoga je temeljno pitanje u izgradnji ekonomije 21. stoljeća usmjereno ka tome kako kreirati novu paradigmu za smisleno djelovanje pojedinca. Ovo je vrlo kompleksno pitanje jer jednim dijelom zadire u slobode pojedinca, ali isto 
tako te slobode mogu ugrožavati prava drugih pojedinaca zbog neslućenih međuzavisnosti koje je donijela (i donosi) globalizacija temeljena na bezgraničnom tehnološkom razvoju. Razvoju koji može u konačnici biti i presudni čimbenik u samouništenju naše civilizacije.

\section{EKONOMSKO VRIJEME POJEDINCA}

Težnja maksimizaciji profita za posljedicu ima intenzivno i kontinuirano djelovanje prema povećanju produktivnosti i efikasnosti svih čimbenika unutar lanca stvaranja dodane vrijednosti. Stoga je sam ljudski rad izložen stalnoj analizi, usmjerenoj ka smanjenju njegovog troška uz povećanje dobiti koja se generira kroz njegovu transformaciju u proizvod ili uslugu. Razlika nastala između dobiti i utrošenog ljudskog rada definira produktivnost i efikasnost samog procesa u kojem se rad odvija, no ona isto tako ima implikacije i na ostale društvene procese (Porter, 1998). Pojedinac sudjeluje u tržišnoj reprodukciju kroz potrošnju, vlastiti rad, investiranje i društveno djelovanje. Činjenica je da su nužnost rada u proizvodnji i zadovoljavanje potreba u potrošnji esencijalni i egzistencijalni imperativ svakog ljudskog bića. U takvom cikličkom kolopletu rada i potrošnje, dinamika ekonomskog vremena $\left(\mathrm{T}_{\text {en }}\right)$ nameće se kao prioritetna nad ostalim vremenima kojima je determiniran prostor djelovanja suvremenog pojedinca. Dinamičnost ekonomskih procesa tj. protočnost i promjena tržišne vrijednosti dobara u reprodukcijskim procesima, determiniraju ekonomsko vrijeme $\left(T_{e n}\right)$ kroz odnos potrošnje $i$ rada pojedinca. Vremensko djelovanje pojedinca koje otpada na potrošnju i rad definiran je vrijednošću prikazanom na koordinatnoj osi $T_{\text {en }}$ te je sve većeg obujma i intenziteta. Obujam potrošnje u direktnoj je korelaciji s brzinom rada tj. brzinom kojom pojedinac akumulira financijska sredstva neophodna za stjecanje dobara ili usluga. Ukoliko pojedinac želi povećati obujam svoje potrošnje tada je neophodno podići brzinu rada te akumulirati veću količinu financijskih sredstava. Način na koji to pojedinac ostvaruje (fizičkim ili umnim aktivnostima) definira njegovu ulogu u društvenim procesima te direktno ili indirektno utječe na druge dionike u njegovom bližem ili širem okruženju. Svako vrijeme, pa tako i ekonomsko, definirano je trima vremenskim dimenzijama (prošlim, sadašnjim i budućim) koje stvaraju pulsirajući efekt unutar prostora djelovanja pojedinca. U zavisnosti o ravnini djelovanja $(\pi$ ili $\rho)$, ekonomsko vrijeme generira točke koje definiraju oblik prostornog trokuta. Nema osobe koja prema radu ne potiče vlastite potrebe niti ima osobe koja zadovoljavanje potreba ne propulsira vlastitim radom. Suština je u tome da se ljudsko obraćanje rada u vezi s potrebama, i također, potreba u vezi s radom, neprestano posreduje tako da čovjek vlastitim radom zadovoljava potrebe drugih i da radom drugih zadovoljava vlastite potrebe. Druga je bitna činjenica da takav smisao razvoja društvenog života ljudi realno nije moguć bez određenog poretka kojim se održava temeljni imperativ progresa. Bližim pristupom takvom shvaćanju ljudi u reprodukciji njihovog vlastitog života dolazi se do postavke da svako ljudsko biće podliježe dvojakoj relaciji svoje društvenosti (Giddens, 2007). Ubrzavanje obujma 
potrošnje podiže razinu intenziteta i značaja ekonomskog vremena nad ostalim vremenima (društvenim i ekološkim) te ga sve više zrcali u radnim procesima. Inzistiranje na sve većoj produktivnosti rada potaknuto je kompleksnim i intenzivnim odnosima na globaliziranom svjetskom tržištu. Ovaj trend nesmiljeno iziskuje od pojedinca isključivu usmjerenost na rad i potrošnju, ne ostavljajući mu vremena za djelovanje na ostalim poljima koji društvo čine učinkovitijim.

Ekonomski modeli temeljeni na bezgraničnom poticanju potrošnje kao generatora rasta i razvoja dosegnuli su točku kada pojedinac više nije u mogućnosti uskladiti brzinu rada (putem koje akumulira financijska sredstva) s obujmom svoje potrošnje (količinom financijskih sredstava kojima zadovoljava svoje egzistencijalne i neegzistencijalne potrebe). Unatoč tome što je industrijalizacija i masovna proizvodnja pridonijela podizanju kvalitete življenja te materijalna dobra učinila dostupnim širem sloju stanovništva, dosegnuta je točka kada postojeći ekonomski modeli većini ne mogu pružiti zadovoljavajuću sadašnjost i perspektivnu budućnost.

Ovo stanje karakterizira prije svega društvene sustave razvijenih gospodarstava no i onima gospodarstvima koja teže dostići životni standard razvijenih zemalja vrlo brzo prijeti isti scenarij. Stoga je potrebno žurno pokrenuti procese redefiniranja postojećih ekonomskih modela i to prije svega korigiranjem međuodnosa obujma potrošnje i brzine rada unutar ekonomskog vremena. Kako bi to ostvarili potrebno je mijenjati dosadašnji smisao ekonomskog djelovanja po kojoj se isključivo potrošnjom mogu nadomjestiti potrebe pojedinca koje ga istovremeno čine društvenim i individualnim bićem. Upravo redefiniranje međuodnosa unutar ekonomskog vremena predstavlja začetak kreiranja nove ekonomske filozofske paradigme 21. stoljeća tj. ekonomije smisla.

\subsection{Vrijeme rada}

Robni karakter gospodarstva ogleda se u činjenici da više nije cilj proizvodnje proizvesti takove korisne proizvode koji su potrebni ne samo proizvođaču, već i one proizvode koji se traže na tržištu i mogu se prodati (Norton, 1992). Iz takove masovne proizvodnje nastaje tržišna vrijednost proizvoda, a kako se proizvod razmjenjuje između proizvođača i kupca javlja se i prometna vrijednost proizvoda. Sada proizvođač nije zainteresiran samo za korisnost svoga proizvoda, već i za troškove proizvodnje i za prodajnu cijenu koju njegov proizvod može ostvariti na tržištu. Proizvodnjom roba iznad razine vlastitih potreba pojedinac je, akumuliranjem viškova, stvorio preduvjete nastanka trgovine kao poslovnog procesa (Grossman i Helpman, 1991). Sadašnji gospodarski trendovi teže objedinjavanju ponude i potražnje u jednu cjelinu te na taj način žele maksimizirati njihovu međuzavisnost. Ovim procesom težnja za dobrima i uslugama svojim obujmom sve više utječe na brzinu rada čime pojedinac biva uhvaćen u zamku da sve više svog vremena odvaja za rad (fizički ili umni) putem kojeg nastoji stvoriti financijski potencijal za ostvarivanje svojih želja. Tehnološki napredak mijenja tradicionalne oblike i modalitete rada te pojedinca komprimira u vremenski sve ubrzaniji prostor u kojem dominira ekonomsko vrijeme. Kompleksnost poslovnih procesa te globalizacija svjetskog tržišta pred 
pojedinca stavlja nove radne izazove koji ga sve više okupiraju i smanjuju njegov potencijal društvenog i ekološkog djelovanja. Umjesto da tehnološkim razvojem stvara višak vremena (smanjuje brzinu rada zbog manjeg vremenskog intervala potrebnog da ostvari iste ili veće financijske koristi) te ga usmjerava prema izvan ekonomskim aktivnostima, pojedinac povećava obujam svojih potreba te tako anulira generirani višak vremena. $\mathrm{Na}$ ovaj način stvara dvostruko negativan efekt: nekontrolirano crpi prirodne resurse i generira socijalne sukobe. Rezultat ovakvog međuodnosa unutar vremenskog prostora djelovanja pojedinca iskazuje se kroz globalnu eko-socijalnu krizu koja dugoročno ugrožava opstojnost života na našem planetu.

\subsection{Obujam potrošnje}

Sociološki gledano potrošnja kao pojam predstavlja svako društveno djelovanje pojedinca, skupine ili institucije koje započinje procesom kupnje tj. plaćanjem neke robe (dobara, proizvoda, usluga ili iskustva) koja zadovoljavaju određenu potrebu, ali i ispunjavaju svrhu nekog djelovanja. Potrošnjom se može konzumirati, sačuvati, riješiti neki problem korisnika te nešto doživjeti (Čolić i Peračković, 2013). Svođenje iskazivanja pojedinca na težnju za posjedovanjem nekog materijalnog dobra determinira potrošnju kao imperativ, a potrošačka kultura postaje dominantni čimbenik društvenog djelovanja. Dominantne društvene vrijednosti ne samo da su organizirane kroz prakse potrošnje nego u određenom smislu i proizlaze iz njih (Slater, 2004). Potrošnja kao primarno ekonomska kategorija ima novu društvenu funkciju i postaje jedan od najvažnijih elemenata kulture u društvima suvremenog, globalnog kapitalizma. Donošenje odluke o kupnji sadrži slijedeće korake: 1) javljanje potrebe; 2) obrada informacija; 3) vrednovanje marki; 4) kupnja; 5) vrednovanje poslije kupovine (Milas, 2007). Budući da je inicijalni čimbenik ovog procesa želja, suvremena tržišna ekonomija nastoji je poticati i transformirati je u potrošnju. Pritom se malo pažnje posvećuje ekološki održivoj strukturi i usmjerenosti same potrošnje, a sve je podređeno profitu kao isključivom mjerilu tržišne konkurentnosti. Upravo ovakvo sagledavanje svrhe ekonomskog djelovanja može u današnjem umreženom svijetu, ulogu potrošnje kao pokretača kratkoročnog rasta preusmjeriti u faktor nestabilnosti koji generira gospodarske krize globalnih razmjera.

Ako današnja društva definiraju „robno građanstvo“, tada je efikasnost implementacije održivog razvoja determinirana stupnjem (razinom) transformacije današnjeg određenja vrijednosti robe. Vrijednosna transformacija robe s ciljem uspostavljanja uravnoteženog razvoja svih društvenih dimenzija (ekoloških, socijalnih i ekonomskih), nameće se kao nužnost kojom se mogu spriječiti buduće krize te će se tržišna ekonomija razvijati na platformi održivog razvoja.

Obujam potrošnje, kao spoj racionalnog i iracionalnog društvenog djelovanja glavni je pokretač kapitalističke ekonomije, a potrošači ključni akteri njenog opstanka (Čolić i Peračković, 2013).

U takvom ekonomskom modelu međuodnos potrošnje i prihoda pojedinca, determinira stanje unutar određenog društvenog sustava (Slika 2). 


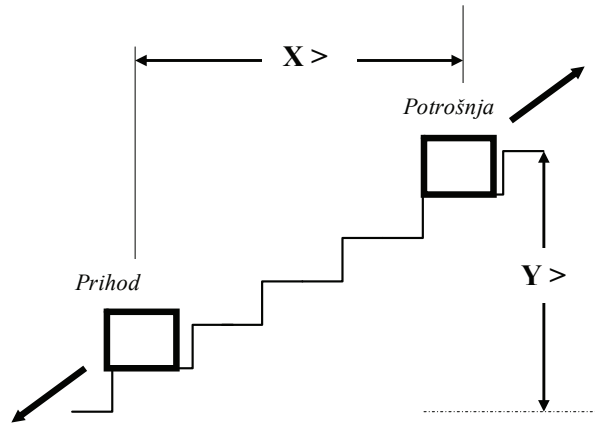

Društvena nestabilnost

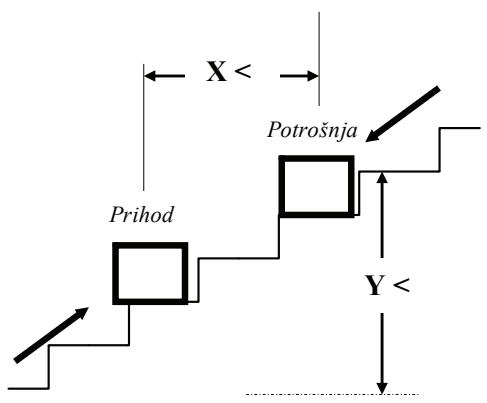

Društvena ravnoteža

\section{Slika 2. Potrošnja i prihod kao odrednice društvene nestabilnosti / ravnoteže}

Povećani gospodarski rast $(\mathrm{Y})$ potaknut potrošnjom u korelaciji je s prihodima koje ostvaruje pojedinac kroz svoj rad. Postojeći ekonomski modeli stoga fokusiraju svoju aktivnost na poticanje potrošnje koja je sve više u raskoraku s realnim mogućnostima pojedinca (X), a što se nastoji premostiti različitim financijskim transakcijama (plasmanom potrošačkih kredita, kartičnim plaćanjem s odgodom i sl.). Rezultat toga je da vrijeme rada kontinuirano raste i sve je više uvjetovano vanjskim čimbenicima koji nisu pod direktnim utjecajem samog pojedinca. Nameće se pitanje: Gdje je granica na kojoj potrošnja unutar tržišno reprodukcijskog sustava direktno ili indirektno ugrožava ostale sustave koji neko društvo čine učinkovitim i svrsishodnim za svakog njenog člana? Tu granicu potrošnje potrebno je iščitati unutar nove platforme tržišnog djelovanja, a koja će biti izgrađena na održivim razvojnim stupovima (ekonomskim, ekološkim i socijalnim). Unutar te platforme ključnu ulogu imati će tzv. održiva konkurentnost koja će u sebi sublimirati ekonomske i društveno razvojne čimbenike.

\section{DRUŠTVENO VRIJEME POJEDINCA}

U potrošačkom društvu sloboda kao stanje postaje usko orijentirano, te gubi značaj koji je ista imala u prošlosti. Sloboda bez egzistencijalne slobode nije potpuna tj. njene blagodati se ne mogu u potpunosti konzumirati. Paradoks slobode upravo ukazuje na činjenicu da rasne, religijske, seksualne, jezične i ine slobode u konačnici uzmiču pred egzistencijalnom slobodom.

Da bi stekao egzistencijalnu slobodu pojedinac sve više vremena odvaja za rad dok je vrijeme predviđeno za društveno djelovanje i potpomaganje unutar određene zajednice minimalizirano. Duh individualizma koji se promiče kroz neoliberalnu paradigmu slobodnog tržišta zatomio je ljudsku potrebu za samorealizacijom unutar kolektiva tj. društvenog sustava. Struktura i obujam društvenog i ekološkog djelovanja sve više uzmiče pred dominantnim ekonomskim djelovanjem. U tako narušenom međuodnosu pojedinac sve više gubi alate samoupravljivosti, a dvosmjernost djelovanja (društva spram 
ekonomije i obrnuto) ugrožava prostorne potencijale na lokalnoj i globalnoj razini (Slika 3). Društveno djelovanje (kotač 1 ) svojim intenzitetom i smjerom djelovanja prema ekonomiji (kotač 2) ili ekologiji (kotač 3) determinira ravnotežu međuodnosa unutar trokuta djelovanja (društvenog, ekonomskog i ekološkog) na način da smanjuje ili povećava distance među kotačima 1,2 i 3 .

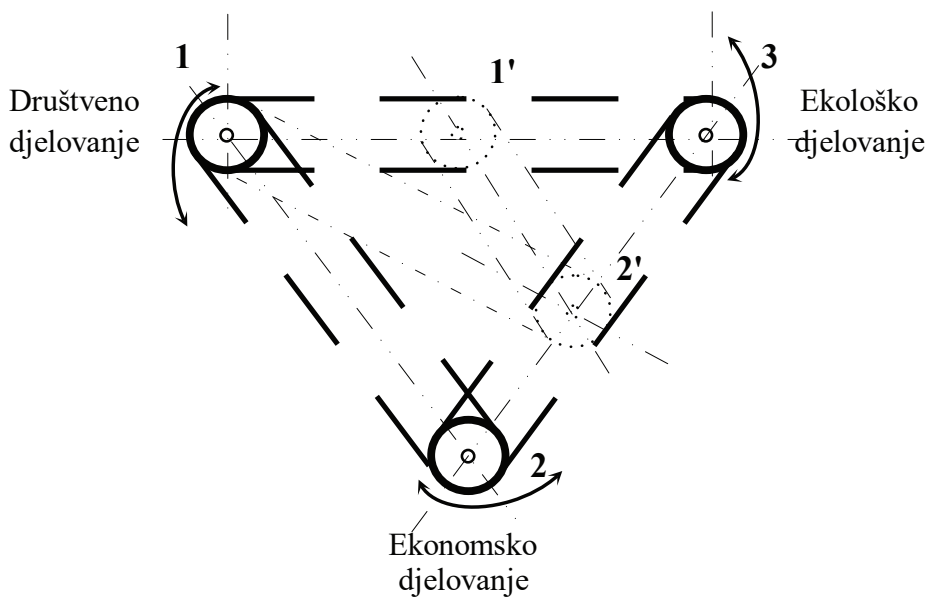

Slika 3. Međuodnos društvenog, ekonomskog i ekološkog djelovanja

Izjednačavanjem svih distanci između kotača 1, 2 i 3 postiže se ravnoteža, a koja se narušava dvosmjernim djelovanjem društvenog spram ekonomskog, što rezultira promjenom položaja kotača 2 u položaj 2'. Na ovaj način dolazi do destabilizacije unutar trokuta djelovanja i ekonomija vrši pritisak na ekologiju. Kako bi došlo do ponovne uspostave ravnoteže potrebno je snažnije društveno djelovanje spram ekologije (iz položaja 1 u položaj 1'). Sve ovo ukazuje na značaj društvenog djelovanja čiji je temeljni pokretač sam pojedinac. Prvi put u ljudskoj povijesti stvorili su se preduvjeti da pojedinci mogu komunicirati međusobno na globalnoj razini te se na taj način zaobilaze zapreke koje mogu nastati unutar društvenih sustava u kojima djeluju (Dragičević, 1996). Protok informacija i tehnološka revolucija svakim danom pojedincu otvaraju nove mogućnosti da se egzistencijalno realizira te da njegova zavisnost po pitanju materijalnog bude tim manja.

Sve ovo pojedincu otvara neslućene mogućnosti no istovremeno i komprimira njegov prostor djelovanja ubrzavajući njegovo vrijeme, pa realni tj. prirodni prostor zamjenjuje sve više virtualnim prostorom. Veličina vremenskog djelovanja pojedinca u prostoru definirana je veličinom iskazanom na koordinatnoj osi $T_{d r}$ te je $u$ direktnoj korelaciji s ekonomskim vremenom. Kako je pojedinac direktni sudionik u ekonomskim procesima kroz istovremenu ulogu potrošača i radnika, obujam društvenog djelovanja determinira njegovo društveno vrijeme $\left(\mathrm{T}_{\mathrm{dr}}\right)$. Sve veća individualizacija $\mathrm{i}$ fokusiranje na ostvarivanje vlastitog komoditeta značajno su umanjili uključenost pojedinca u opće društvene procese. U prostoru svog djelovanja tako pojedinac sve manje vremena ima za 
djelovanje izvan reprodukcijskog procesa čiji je i sam aktivni dionik (kao radnik ili potrošač). Tendencija vertikalnog rasta pulsirajuće točke 1 duž koordinatne osi $T_{\text {en }}$ unutar ravnine $\rho$ je stoga rezultat kontinuiranog smanjenja obujma društvenog vremena spram ekonomskog vremena (Slika 1). Količina vremena koju je pojedinac spreman izdvojiti za društveno djelovanje preko obujma društvenog djelovanja direktnoj je korelaciji s ekonomskim vremenom $\left(\mathrm{T}_{\mathrm{en}}\right)$. Potrošačka kultura postaje dominantna društvena kultura koja je generirana kontinuiranim iskazivanjem žudnje (engl. desire) pojedinca za postizanjem sve većeg osobnog komoditeta. Žudnja kao pojam razlikuje se i od potreba (engl. needs) i od želja (engl. wants) jer umjesto usmjerenosti ka zadovoljenju teži vlastitoj reprodukciji te je $s$ materijalne strane možemo sagledati u kontekstu iracionalne težnje pojedinca za stjecanjem dobra u cilju iskazivanja svog društvenog bitka. Međuzavisnost društvenog i ekonomskog vremena reflektira se na položaj pulsirajuće točke 2. unutar ravnine $\lambda$ koja definira društveno-ekološki odnos. Na taj način ekonomsko djelovanje putem smanjenja potencijala društvenog djelovanja determinira ekološko vrijeme kroz iskazanu veličinu na koordinatnoj osi $\mathrm{T}_{\text {ek }}$.

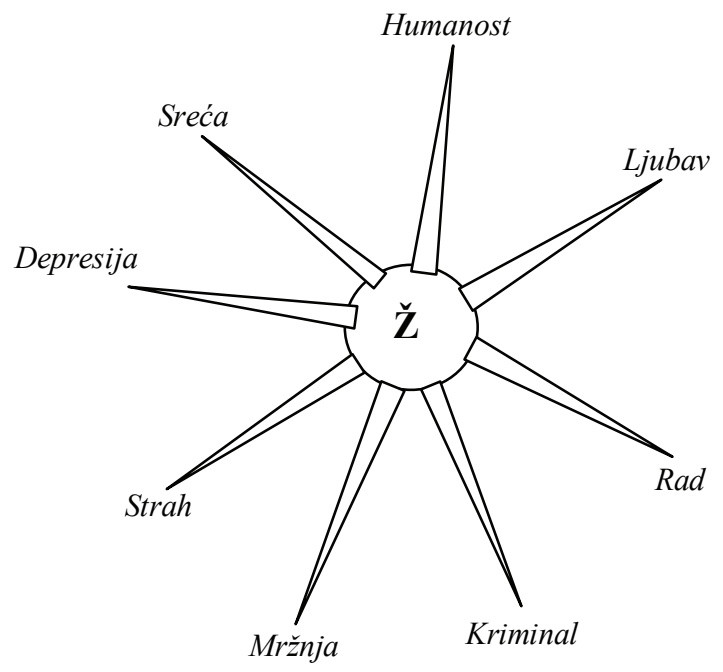

Slika 4. Žudnja kao pokretač stanja i djelovanja pojedinca

Žudnja kao pokretač različitih stanja i djelovanja (Slika 4) može imati pozitivne i negativne posljedice kako za samoga pojedinca tako i za cijelo društvo (prostor) u kojemu on djeluje. Ukoliko pojedinačnu žudnju sagledamo u kontekstu društva, tada za implementaciju održivog razvoja na platformi ekonomije smisla presudno značenje ima uspostavljanje ravnoteže između potrošačke i društvene kulture. Žudnjom koja generira potrošnju pojedinac determinira strukturu i obujam društvenog vremena koje sve više poprima svrhu potpomaganja aktivnosti kojima se potiče ekonomsko vrijeme. U ta- 
kvom međuodnosu vrijeme namijenjeno za društveno djelovanje pojedinca svedeno je na minimum te je individualizirano tj. strukturirano prema isključivom zadovoljavanju osobnih interesa. Djelovanje u općem interesu postaje interpretirano kao nepoželjno te se aktivira samo u slučajevima određenih ugroza unutar društva. Društvo putem svojih institucija stoga mora u okvirima mogućeg kreirati takve kulture koje će istovremeno dozvoljavati individualnu žudnju, ali kojom se neće narušiti cjelokupna ravnoteža istog. Globalizacija je značajno otežala ove procese jer su se informacijski kanali neslućeno proširili, a tradicionalne vrijednosti su se pod utjecajem tzv. zaštitnika individualnih sloboda sve više potiskivale, čime se žudnja kao osobno pravo pojedinca razvilo u temeljni alat ekonomske doktrine koja uspostavlja vrijednosne kriterije determinirane isključivo stvaranjem profita kao jedinog mjerila uspjeha. Sve ovo nagriza temeljne vrijednosti suvremene civilizacije te zahtjeva ponovno vraćanje $\mathrm{u}$ fokus važnost obujma i strukture društvenog vremena kao nužnog čimbenika u izgradnji samosvjesnog pojedinca neophodnog za uspostavu uravnoteženog i održivog društvenog sustava.

\section{EKOLOŠKO VRIJEME POJEDINCA}

Poticanje „industrije žudnje“ u svrhu funkcioniranja globalnog ekonomskog modela, osim tzv. nikad većeg standarda i kvalitete življenja pojedinca, nosi sa sobom i snažne razorne posljedice kako za društvo tako i za okoliš u kojem to društvo obitava. Kontinuirano inzistiranje na partikularnosti i individualnosti kod pojedinca u potpunosti je potisnulo osjećaj za kolektivno te djelovanje u sadašnjem vremenu koje neće naštetiti potencijalu budućeg vremena (Radermacher, 2003). Teza „uzmi sada sve jer sutra može biti kasno" generira galopirajući konzumerizam kao stil života kojim se sve snažnije djeluje na okolišs, a što za posljedicu ima značajne klimatske promjene. Povezanost ekološkog vremena $\left(\mathrm{T}_{\mathrm{ek}}\right)$ tj. vremena koje pojedinac troši na očuvanje svog okruženja, $s$ ekonomskim i društvenim aktivnostima uočava se kroz položaj pulsirajućih točaka $2 \mathrm{i}$ 3 u ravninama $\pi$ i $\lambda$. Veličina ekološkog vremena determinirana je koordinatnom osi $\mathrm{T}_{\text {ek }}$ koja zajedno $s$ koordinatnim osima $\mathrm{T}_{\text {en }} \mathrm{i} \mathrm{T}_{\mathrm{dr}}$ definira prostor djelovanja pojedinca. Iz takvog međuodnosa jasno se uočava direktna zavisnost ekološkog vremena $\left(T_{e k}\right)$ o međuodnosu obujma generiranog otpada i brzine rada koja utječe na obujam potrošnje koji sve intenzivnije generira otpad. Ekonomsko vrijeme $\left(T_{\text {en }}\right)$ i vrijeme potrošnje kroz svoje direktno međudjelovanje u direktnoj su korelaciji s obujmom generiranog otpada Pulsirajuća točka 3 definira intenzitet odnosa ekološkog i ekonomskog vremena. Prostorni trokut s pulsirajućim vrhovima (točkama 1, 2 i 3) za polaznu točku uzima međuodnos ekonomskog i društvenog vremena tj. točku 1 prikazanu u ravnini $\rho$. Tako kreiran prostorni trokut važnost ekološkog vremena minimizira te generira kontinuiranu deformiranost istog što se iskazuje kroz sve učestalije globalne eko-socijalne krize. Kako i u kojem obliku će se dalje razvijati odnos potrošnje pojedinca i okoliša u kojem isti obitava uvelike će ovisiti o stupnju razvoja tehnologija koje će nastojati pomiriti potrebe pojedinca za imanjem i štetnost po okoliš koju ta težnja može izazvati.

Suvremeni gospodarski procesi temeljeni na kontinuitetu potrošnje i proizvodnje bez 
jasno reguliranih i kontrolnih aktivnosti, imaju za posljedicu ogromnu količinu žudnje koju pojedinac iskazuje u odnosu na dobra koja mu stoje (ili ne stoje) na raspolaganju (Pearce i sur., 1990). Zanemarivanjem ostalih faktora koje tvore jednu cjelinu (kao što je država) tj. društvo i okoliš, za rezultat ima narušenu ravnotežu koja generira nastanak potencijalnih točaka sukoba. Ekološko vrijeme stoga postaje primarna točka fokusa ekonomije smisla, odnosno točka koja determinira strukturu i obujam ekonomskog $\left(\mathrm{T}_{\mathrm{en}}\right)$ i društvenog $\left(\mathrm{T}_{\mathrm{dr}}\right)$ vremena. Ekološko vrijeme $\left(\mathrm{T}_{\mathrm{ek}}\right)$ sve više dobiva na značaju upravo zbog povratnog efekta prirode koje se očituju kroz klimatske promjene i njihov utjecaj na gospodarske i društvene procese. Isključivost ekonomskog vremena poremetila je vremenski prostor djelovanja pojedinca generirajući devijacije koje su se $s$ društvenih procesa prenijele na okolišs, a što za rezultat ima sve snažniju i razorniju eko-socijalnu globalnu krizu (Beard i Lozada, 1999).

\section{POJEDINAC U VREMENSKI DETERMINIRANOM PROSTORU}

Ekonomsko vrijeme $\left(\mathrm{T}_{\text {en }}\right)$ kao temeljna odrednica prostora u kojem djeluje suvremeni pojedinac uvjetuje tj. kreira strukturu i obujam društvenog vremena $\left(\mathrm{T}_{\mathrm{dr}}\right)$ pojedinca koje svojim slijedom značajno formira oblik ekološkog vremena $\left(T_{\text {ek }}\right)$. Razvidno je da su društveno, a pogotovo ekološko vrijeme suvremenog pojedinca u funkciji ekonomskog vremena tj. potrošnja i rad nametnuli su se u prostoru vremenskog djelovanja pojedinca. Društveno vrijeme $\left(\mathrm{T}_{\mathrm{dr}}\right)$ iskazano kroz ekonomsko vrijeme $\left(\mathrm{T}_{\mathrm{en}}\right)$ ukazuje da brzina i obujam potrošnje sve više ubrzava rad pojedinca. Ovo iziskuje sve veću efikasnost i produktivnost pojedinca koja se jednim dijelom ostvaruje tehnološkim napretkom, a drugim kroz intenzivnu eksploataciju rada (sve više rada za niže nadnice). Fizička ograničenost ljudskog radnog potencijala stoga bi trebala determinirati i gornju granicu potrošačkog potencijala tj. obujma potrošnje. Osim ovog ograničenja sve veći pritisak na promjenu u vremenskom prostoru djelovanja pojedinca ima i ekološko / prirodno ograničenje. Sve ovo ukazuje na nužnost promjene polazišnih točaka u kreiranju prostornog trokuta. Djelovanjem suvremenog pojedinca u vremenski determiniranom prostoru može se upravljati ako se definiraju međuodnosi ovih vremena te se određenim alatima nastoji utjecati na uspostavljanje što veće ravnoteže iskazane kroz jednakokračnost prostornog trokuta prikazanog na Slici 1. Prostorni trokut determiniran je pulsirajućim točkama 1, 2 i 3, te je izložen kontinuiranoj tendenciji dominacije ekonomskog vremena $\left(T_{\text {en }}\right)$ nad društvenim $\left(\mathrm{T}_{\mathrm{dr}}\right)$ i ekološkim vremenom $\left(\mathrm{T}_{\text {ek }}\right)$. Rezultat ovakvog stanja intenzivnije je i snažnije djelovanje na ekološko-društvene odnose, a koji su determinirani međuodnosom ekološkog i društvenog vremena unutar ravnine $(\lambda)$. Pulsirajuće točke 1,2 i 3 unutar pojedinih ravnina $\rho, \pi$ i $\lambda$ definirane su $s$ trima vremenskim dimenzijama i to: sadašnjost, prošlost i budućnost. Analizirajući prostorni trokut jasno se uočava uzročno-posljedična veza između povećanja ekonomskog vremena $\left(T_{\text {en }}\right)$ iskazanog vremenom rada i obujmom potrošnje, na smanjenje obujma i kvalitete (strukture) društvenog $\left(\mathrm{T}_{\mathrm{dr}}\right)$ i ekološkog $\left(\mathrm{T}_{\mathrm{ek}}\right)$ vremena. Ova međuzavisnost uočljiva je kroz 
neujednačenost prostornog trokuta te površine unutar ravnine $\lambda$ koju determiniraju društveni i ekološki vremenski odnosi. Neoliberalna ekonomska doktrina nametanjem ekonomskog vremena kao temeljnog čimbenika samorealizacije suvremenog pojedinca izvršila je snažan pritisak na društvene i ekološke procese mijenjajući obujam i strukturu njihovog vremena. Takav trend stvorio je globalnu eko-socijalnu krizu koja dugoročno prijeti urušavanjem temeljnih vrijednosti suvremene civilizacije (Daly, 1996).

Upravo zato ekonomija smisla kao jedan od svojih primarnih ciljeva ima stvaranje alata kojima će pojedinac ponovo vratiti kontrolu nad svojim kretanjem unutar vremenskog prostora u kojem djeluje. Tehnološki razvoj tj. informacijska umreženost, omogućava suvremenom pojedincu da bez fizičkog kretanja unutar vremenskog prostora može djelovati u svim njegovim točkama. No, bez obzira na te mogućnosti virtualizacije prostora kroz korištenje suvremenih tehnologija, pojedinac nužno mora djelovati na prostornom uravnoteženju vektorskog trokuta, s ciljem smanjenja pritiska na prostor determiniran društvenim $\left(\mathrm{T}_{\mathrm{dr}}\right)$ i ekološkim $\left(\mathrm{T}_{\mathrm{ek}}\right)$ vremenom tj. na ravninu $\lambda$. Kontinuiranim procesima uravnoteženja pulsirajućih točaka 1,2 i 3 unutar ravnina $\rho, \pi$ i $\lambda$, stvaraju se preduvjeti za jednakokračnost prostornog trokuta kroz promjenu međuodnosa vremenskih veličina $T_{d r}, T_{\text {ek }} i T_{\text {en }}$. Na ovaj način značajno se povećava površina utjecaja vektorskog trokuta u ravnini $\lambda$ koja je determinirana društvenim $\left(\mathrm{T}_{\mathrm{dr}}\right)$ i ekološkim $\left(\mathrm{T}_{\mathrm{ek}}\right)$ vremenom. Većom površinom disperzira se negativni utjecaj ekonomskog vremena na ravninu determiniranu društvenim i ekološkim vremenom tj. pojedinac u vremenski determiniranom prostoru mijenja svoje prioritete djelovanja te uravnotežuje svoje aktivnosti stvarajući preduvjete svom dugoročno održivom razvoju. Slijed djelovanja s ekonomskog na društveno vrijeme ima za posljedicu stvaranje određene kulture djelovanja koje se negativno reflektiraju na okoliš kroz smanjen intenzitet i obujam ekološkog vremena pojedinca (Faucheux i O'Connor, 1998). Zanemarivanje ekološkog vremena kao najmanje prioritetnog vremena za suvremenog pojedinca zaokupljenog kulturom potrošnje, ima za posljedicu negativan reverzibilan proces prirode u odnosu na samog pojedinca. Prirodno vrijeme tj. vrijeme koje imaju prirodni procesi u čijem vremenskom prostoru djelovanja prevladava nagonska potreba za materijalnim stjecanjem iskazanim kroz ekonomsko vrijeme dualnog karaktera (vrijeme rada i vrijeme potrošnje)pojedinac grubo marginalizira i okupira. Misija ekonomije smisla kao temeljne platforme ekonomije 21. stoljeća predstavlja upravo ukidanje dualnosti ekonomskog djelovanja pojedinca kako bi se prekinulo kontinuirano stvaranje procesa koji generiraju globalnu eko-socijalnu krizu.

\section{ZAKLJUČAK}

Kako su sva dobra u prirodi oskudna, svaki pojedinac, bilo kao potrošač ili proizvođač, želi sebi osigurati kvalitetan i hedonistički život. U svojoj želji da to i ostvari sputava ga upravo činjenica da su resursi oskudni ali i činjenica da upravo zbog oskudnosti resursa njegov hedonizam može biti osiguran samo na teret neke druge osobe. Upravo ovo prebacivanje tereta na druge osobe u suvremenom globaliziranom gospodarstvu postaje 
sve teže, te generira nove potencijalne točke sukoba. Ovaj trend nesmiljeno iziskuje od pojedinca isključivost usmjerenu na rad i potrošnju, ne ostavljajući mu vremena za djelovanje na ostalim poljima koji društvo čine učinkovitijim. Svođenje društvenog iskazivanja pojedinca na težnju za posjedovanjem nekog dobra, determinira konzumerizam kao imperativ u ostvarivanju njegovog bitka. Ekonomija smisla je ostvariva transformacijom ekonomije kakvu danas poznajemo i to prije svega putem inverzije osobnosti pojedinca (kao i inverzije odnosa i institucija) na dva načina: interno (svjesnošću važnosti promjene svog društvenog djelovanja) i eksterno (ugrozama koje su determinirane devastacijama biokapaciteta planeta). Na putu ostvarenja ove vlastite pretvorbe nalazi se niz prepreka od kojih su najveće: pragmatizam (sagledavanje problema isključivo kroz fokus vlastitog interesa zanemarujući posljedice koje pritom mogu nastati po širu zajednicu) i globalna nejednakost (spremnost na bezuvjetno poduzimanje svakojakih aktivnosti kako bi se osigurala vlastita egzistencija). Negativni utjecaj krajnosti potrošačkih navika suvremenog čovjeka očituje se i u njegovoj općedruštvenoj i političkoj pasivnosti.

Upravo ova činjenica ukazuje na nužnost rehabilitacije aktivnog pojedinca tj. pojedinca koji nije „umrtvljen“ potrošačkim mentalitetom temeljem kojeg formira vlastito djelovanje. Svođenjem smislenosti postojanja na zadovoljavanje potreba za materijalnim dobrima tržišna ekonomija ostvaruje svoje ciljeve, no sve manje se ostvaruju ciljevi društva u cjelini. U toj nesmiljenoj trci za stjecanjem dobara koja znače statusni simbol u potrošačkom društvu, sve se oštrije i rigoroznije teži povećanju potrošnje. Stoga se logičnim nameće pitanje: Kada potrošnja unutar tržǐ̌no reprodukcijskog sustava direktno ili indirektno dugoročno ugrožava opstojnost života na našem planetu? Tu granicu potrebito je iščitati unutar nove platforme tržišnog djelovanja, a koja će biti oslonjena na održivo uravnoteženim razvojnim stupovima (ekonomskim, ekološkim i socijalnim). Unutar te platforme ključnu ulogu imati će tzv. održiva konkurentnost čija je implementacija uvjetovana vrijednosnom transformacijom roba unutar reprodukcijskog procesa. Jedan je od ključnih preduvjeta za tu realizaciju uravnoteženje aktivnosti pojedinca unutar prostora svog djelovanja determiniranog ekonomskim $\left(\mathrm{T}_{\mathrm{en}}\right)$, društvenim $\left(\mathrm{T}_{\mathrm{dr}}\right)$ i ekološkim $\left(\mathrm{T}_{\mathrm{ek}}\right)$ vremenom. Postojeća ekonomska filozofska platforma unutar svog procesa djelovanja ugradila je sistemsku pogrešku (neograničeni rast i profit kao neupitno mjerilo razvoja) koja onemogućava provođenje održivog razvoja zasnovanog na načelima uravnoteženih eko-socijalno-tržišnih procesa, a što predstavlja nukleus ekonomije smisla kao nove ekonomske filozofske paradigme. 


\section{LITERATURA}

Adam, B. (1990). Time and Social Theory. Cambridge: Polity Press.

Baletić, Z. (1995). Ekonomski leksikon. Zagreb: Leksikografski zavod Miroslav Krleža i Masmedia.

Bauman, Z. (2011). Tekuća modernost. Zagreb: Naklada Pelago.

Beard, R. i Lozada, G. A. (1999). Economics, Entropy and the Environment - The Extraordinary Economics of Nicholas Georgeşu-Roegen. Cheltenham: Edward Elgar Publishing Ltd.

Cifrić, I. i Trako, T. (2010). Društvo i okoliš u vremenskoj perspektivi. O sociologiji vremena i menadžmentu vremena. Sociologija i prostor, 48(1): 19-49.

Čolić, S. (2008). Sociokulturni aspekti potrošnje, potrošačke kulture i društva. Društvena istraživanja, 17(6): 953-973.

Čolić, S. i Peračković, K. (2013). Potrošačka kultura i konzumerizam. Zagreb: Institut društvenih znanosti Ivo Pilar.

Daly, H. E. (1996). Beyond growth: The Economics of Sustainable Development. Boston, MA: Beacon Press.

Dragičević, M. (1996). Ekonomija i novi razvoj. Zagreb: Alinea.

Faucheux, S. i O'Connor, M. (1998). Valuation for Sustainable Development: Methods and Policy Applications. Cheltenham: Edward Elgar.

Giddens, A. (2007). Sociologija. Zagreb: Nakladni zavod Globus.

Goodstein, E. S. (1999). Economics and the Environment. Upper Saddle River, NJ: Prentice Hall.

Grossman, G. M. i Helpman, E. (1991). Innovation and Growth in the Global Economy. Cambridge, MA: The MIT Press.

Milas, G. (2007). Psihologija marketinga. Zagreb: Target.

Norton, B. G. (1992). A New Paradigm for Environmental Management. Covelo, CA: Island Press.

Pearce, D. W., Markandya, A. i Barbier, E. B. (1990). Sustainable Development. London: Earthscan.

Porter, M. (1998). Competitive Advantage: Creating and Sustaining Superior Performance. New York: The Free Press.

Radermacher, F. J. (2003). Ravnoteža ili razaranje: Eko-socijalno-tržišno gospodarstvo kao ključ svjetskog održivog razvoja. Zagreb: Intercon - Nakladni zavod Globus.

Slater, D. (2004). Consumer culture and Modernity. Cambridge: Polity Press.

Stiglitz, J. E. (2009). Uspjeh globalizacije - Novi koraci do pravednog svijeta. Zagreb: Algoritam. 


\title{
ECONOMY OF SENSE AND TEMPORAL DETERMINATION OF THE INDIVIDUAL
}

\author{
Marko Šundov
}

\begin{abstract}
Time, in the context of dominant global economic paradigm, determines individual behaviour in all aspects of social action. The cult of time and the importance of time management became key determinants of individual efforts to achieve self-actualization. The structure and the amount of time available to modern individuals is strongly determined by economic processes, which are imposed onto all social areas in which these individuals act. By taking away their possibility to determine their own time's structure and quantity, they are placed in a subordinate position with regards to the surrounding processes, which in turn makes them more vulnerable to the influence from various interest groups. In turn, materialism run by profit develops an instinctive urge in individuals to possess things, which results in the duality of time, that is, time becomes defined as work and consumption. Additionally, individual' violence toward natural time results in generating increasingly growing and deadly socio-ecological crises, which corrode the fundamental civilizational achievements of modern societies. By equating time with money while, at the same time, encouraging this instinctive need for possession, individuals become exposed to the compression of time and speeding up of their everyday activities. Life becomes more intense and complex, while they become victim to their own desires, which creates an impression of "an impossibility within the world of all possibilities". Therefore, there is a pressing need to redefine existing economic models and put time back into the framework within which individuals can manage it more effectively, i.e. better align their time with natural time. Economy of sense aims to manage time in such a way as to enable a more wholesome control of all social processes that are important for a long-term balanced development, as well as subordinate economy to the individual (as opposed to existing economic model where individuals are subordinate to economic processes on which they have no influence).
\end{abstract}

Key words: time management, duality of time, natural time, socio-ecological crisis, economy of sense

\section{ÖKONOMIE DES SINNS UND ZEITLICHE DETERMINIERTHEIT DES EINZELNEN}

\author{
Marko Šundov
}

\begin{abstract}
Zusammenfassung
Die Zeit im Kontext des vorherrschenden globalen ökonomischen Paradigmas determiniert das Verhalten des Einzelnen in allen Bereichen des sozialen Handelns. Der Kult der Zeit und die Bedeutung des Zeitmanagements werden zu Schlüsseldeterminanten im Handeln des Einzelnen hinsichtlich der Ziele seiner völligen Selbstverwirklichung. Die Struktur und der Umfang der Zeit, über die der zeitgenössische Einzelne verfügt, ist größtenteils durch ökonomische Prozesse determiniert, die allen anderen sozialen Bereichen aufgedrängt sind, in denen er handelt. Der Verlust der Möglichkeit, die Struktur und den Umfang der eigenen Zeit zu verwalten, setzt den Einzelnen in eine unterlegene Lage den Prozessen gegenüber, die ihn umgeben und durch verschiedene Interessengemeinschaften beeinflußbar machen. Der vom Profit getriebene Materialismus entwickelt ein triebhaftes Bedürfnis des Einzelnen nach Haben, die Folge davon ist die Dualität der Zeit, d.h. es ist eine Zeit von Arbeit und Konsum definiert. Das gewalttätige Handeln des Einzelnen der natürlichen Zeit gegenüber resultiert mit dem Schaffen immer größerer und fatalerer sozioökologischer Krisen, die die Grundlagen von zivilisatorischen Errungenschaften der modernen Gesellschaften gefährden. Durch die Gleichsetzung der Zeit mit dem Geld und ein gleichzeitiges Anspornen des triebhaften Habgier ist der Einzelne einer kontinuierlichen Komprimierung der Zeit und Beschleunigung seiner alltäglichen
\end{abstract}


Aktivitäten ausgesetzt. Das Leben wird immer intensiver und komplexer und der Einzelne wird zum Opfer seines eigenen Strebens, wodurch der Eindruck "der Unmöglichkeit in der Welt der Allmöglichkeit" entsteht. Deswegen entsteht das Bedürfnis, die bestehenden ökonomischen Modelle neu zu definieren und die Zeit in den Rahmen zurückzusetzen, innerhalb dessen der Einzelne imstande sein wird, im größeren Maße seine Zeit zu verwalten, d.h. er wird seine Zeit in möglichst hohem Maß an die natürliche Zeit anpassen können. Die Ökonomie des Sinns will gerade durch ihre Wirkung auf die Zeit alle für eine langfristige ausgewogene Entwicklung gesellschaftlichen Prozesse integral verwalten und die Ökonomie dem Eizelnen unterlegen (im Unterschied zum bestehenden Modell, wo der Mensch den ökonomisvchen Prozessen unterworfen wird und sie nicht beeinflussen kann).

Schlüsselwörter: Zeitmanagement, Dualität der Zeit, natürliche Zeit, sozio-ökologische Krise, Ökonomie des Sinns 